\title{
In Melatonin: pregnancy and childbirth
}

\begin{abstract}
In a review summarizes the mechanisms of synthesis of melatonin and its regulatory effect aimed at successful pregnancy and fetal development of functional systems. Shows a synergistic effect of melatonin and oxytocin during pregnancy and childbirth. Underlined the importance of an individual approach to the appointment in childbirth medicines is a physiological antagonist of melatonin.
\end{abstract}

Keywords: melatonin, pregnancy, childbirth, the fetus

Volume I Issue 5 - 2018

\section{Ailamazyan Edward Karpovitch, Evsyukova Inna, Kvetnoy Igor Moiseevich}

Department of physiology and pathology, Research Institute of Obstetrics and Gynecology, Russia

Correspondence: Ailamazyan Edward Karpovitch, Director, RAMS, z.d.n. Russian Federation, Professor. Research Institute of Obstetrics and Gynecology. Ott, 199034. Russia. St. Petersburg. Mendeleev line, 3, Email iagmail@ott.ru

Received: September 20, 2018 | Published: September 25 2018

\section{Introduction}

Melatonin as a regulator of daily and annual cycles of physiological functions of the body and, in particular, the reproductive system of animals and humans in recent years has increasingly attracted the attention of researchers. ${ }^{1-5}$ However, not only changes in melatonin production depending on the length of the light and the dark time of day is determined by seasonal and daily rhythms of reproduction system restructuring, but its unique antioxidant, immunomodulating properties as well as participate in the metabolic processes at the cellular and tissue levels provide reproductive health. ${ }^{6-10}$ Melatonin is synthesized in the pineal gland, ${ }^{11}$ which is the physiological control of the endocrine function to a large extent is light regime. Light information from the retinal ganglion cells through retinohypothalamic tract enters the suprachiasmatic nuclei $(\mathrm{SCN})$ of the hypothalamus, where the signals are in the upper cervical ganglia and then sympathetic noradrenergic pathways reach epiphysis where melatonin is synthesized. ${ }^{12-14}$ Light inhibits the production and secretion of melatonin, so its maximum level in the epiphysis and human blood is observed in the middle of the night, and the minimum - in the daytime. ${ }^{12,15,16}$ The presence of circadian rhythm of melatonin production is a marker for normal operation of the circadian regulation of endogenous biological rhythms and their synchronization with the external rhythm of the daily alternation of day and night. ${ }^{17,18}$ Melatonin is produced not only in the epiphysis. Ekstrapinealny melatonin was found in all organs: the gastrointestinal tract, liver, kidneys, adrenal glands, heart, thymus, gonads, placenta, uterus, platelets, eosinophils, leukocytes, and other cells of the immune system. ${ }^{9,19-23}$ Thus its synthesis in mitochondria of eukaryotic cells indicates unique protection melatonin cellular organelles from oxidative damage and maintaining their physiological functions. ${ }^{7,24,25}$ Melatonin is synthesized from the amino acid tryptophan by hydroxylation of which (an enzyme tryptophan hydroxylase) and decarboxylation (the enzyme 5-oksitriptofandekarboksilaza) is converted into serotonin. Using enzymes $\mathrm{N}$-atsetiltranferazy (NAT) and oxindole-O-methyltransferase (HIOMT) formed of serotonin, melatonin. From pinealocytes pineal melatonin is released into the blood and cerebrospinal fluid, as melatonin is secreted by other cells in the body, it enters the blood in small amounts, giving a field of its synthesis paracrine and autocrine effect. ${ }^{26} \mathrm{With}$ a hydrophilic molecule of melatonin at the same time it is highly lipophilic and therefore easily penetrates the blood-brain and the placental barrier, takes place in the capillaries, where $70 \%$ of melatonin binds to albumin. ${ }^{27}$ The half-life of melatonin ranges from 30 to 45 minutes. ${ }^{8,28}$ Melatonin is metabolized in the liver and kidneys. The end products of metabolism -6-sulfatoksi-melatonin and acetylsalicylic acid.

Melatonin provides regulating effect through binding to receptors. A person identified two types of membrane receptors (MT1 and MT2) and chromosomal localization (chromosome 4q35 and 11q21-22), and nuclear receptors (ROR $\alpha)^{25,29,30}$ Receptors for melatonin detected in suprachiasmatic nuclei of the hypothalamus, the cerebellum, retina, spleen, liver, genital gland, mammary gland, uterus, thymus, gastrointestinal tract, platelets, lymphocytes. ${ }^{12,31-36}$ In the brain revealed numerous specific membrane proteins of melatonin receptors, coupled with guanine nucleotide-binding protein (G-protein) and the maximum shown in the hypothalamus and pituitary gland..$^{37,38}$ Receptor even in the absence of melatonin having high permeability exerts a systemic effect of the molecule at the cellular level by modulating the cytoskeleton and mitotic functions through binding to calmodulin and as a free radical scavenger. ${ }^{39,40}$ It should be noted that melatonin synthesized in the pineal gland, has a modulating effect on the function neurohypophysis in particular allocation of oxytocin, vasopressin, prolactin. ${ }^{41,42}$ Furthermore, melatonin affects the sexual development and reproductive function through local exposure and activation of receptors in the hypothalamus-pituitary-gonadal system. ${ }^{43-45}$ It plays an important role in maintaining the proper function of ovarian follicles and ovulation in the implementation of the progesterone production..$^{10,46-49}$ With the onset of pregnancy, melatonin and circadian rhythm of secretion determine its success and for the birth of a healthy baby. First, the melatonin and its metabolites function as direct absorbers produced during pregnancy of free radicals stimulate antioxidant enzymes, thereby providing a stable protection against free radical damage at the cellular and tissue levels in a single system mother - placenta - fetus. ${ }^{50-55}$ With the ability to inhibit gene expression of inducible NO-synthase and cyclooxygenase melatonin limits the production of proinflammatory molecules (prostanoids, leukotrienes, cytokines, etc.), Thereby carrying out an anti-inflammatory protection. ${ }^{56,57} \mathrm{As}$ an immunomodulator and a regulator of vascular-platelet hemostasis, ${ }^{35,58}$ it is involved in the implantation process, placentation, morphological and functional development of the placenta and the preservation of its neyroimmunoendokrinnoy function, aimed at the formation and establishment of vital functional systems of the fetus. ${ }^{59-61}$ It is shown that the cytotrophoblast and syncytiotrophoblast cells not only contain membrane receptors MT1 and MT2, but they themselves synthesized 
melatonin, providing paracrine, autocrine and intracrine effect in the placenta and is also a powerful antioxidant effect. ${ }^{62,63}$ By adjusting the process retains apoptosis melatonin balance cytotrophoblast and syncytiotrophoblast cells, thereby maintaining homeostasis placenta. Produced in the placenta melatonin is secreted into the amniotic fluid where, researchers believe it performs antioxidant and antiinflammatory effect. ${ }^{64,65}$ If melatonin is synthesized in cells of the amniotic membrane is not yet established. ${ }^{54}$

It is found that the melatonin level in the blood of pregnant increases, particularly after 24 weeks and reaches a maximum before birth. ${ }^{66,67}$ Some researchers attribute this trend increase during pregnancy activity of enzymes involved in the synthesis of melatonin in the pineal gland. ${ }^{68}$ Others, given the fact that melatonin levels during pregnancy raises both at night and in the daytime, as the source of placental considering melatonin, the synthesis of which is much greater than that in the epiphysis. ${ }^{66,67}$ The present data confirm the hypothesis of absence of such dynamics melatonin preeclampsia during pregnancy complication in which the products are greatly reduced due to placental melatonin expression changes and suppressing activity involved in its synthesis enzymes and a significant inhibition of expression of MT1 and MT2 receptors ${ }^{69}$ It is believed that pregnancy-related changes ekstrapinealnogo production of melatonin in the placenta, the fetus, in a woman's body, along with the increasing role of the epiphyseal maternal melatonin define the conditions for optimum adaptation to the pregnancy of all functional systems and preparing for the birth of the child. ${ }^{49}$ Penetrates easily to the fetus maternal melatonin plays a key role in the functional development of the central nervous system and its formation of the circadian rhythms of life. ${ }^{70,71}$ After delivery of melatonin levels is greatly reduced in the daytime and night-time. ${ }^{54}$ Numerous studies in recent years have shown a close one-way interaction of melatonin and oxytocin during pregnancy and childbirth. It is known that production of oxytocin in decidual tissue increases during the third trimester of pregnancy and particularly immediately before birth, ${ }^{72}$ uterine sensitivity to oxytocin during pregnancy increases by $10-20$ times and reaches its maximum at the time of delivery to a large extent due to the activation of the oxytocin receptor gene. ${ }^{73}$ Oxytocin acts on the muscle fibers, reducing the resting potential of the cell membrane, and thereby muscle stimulation threshold, thereby increasing the frequency and intensity of uterine contractions. ${ }^{74}$ It increases the production of prostaglandins in fetal membranes and stimulates the synthesis and release of cytokines, involved in the regulation of formation of prostaglandins ${ }^{73-76}$ Circadian rhythm of secretion of oxytocin occurs during pregnancy, does not change with changing light conditions and to a large extent determines the circadian rhythm offensive birth. ${ }^{77,78}$ In recent years, gene expression is detected circadian clock directly in the uterus of nonpregnant and pregnant rodents and suggested the hypothesis that it is the melatonin circadian signal which initiates the onset of labor. ${ }^{79}$ This is also evidenced by the results of experimental studies have shown that in rats the onset of childbirth did not depend on the time of day when the removal of the pineal gland, but the circadian rhythm was restored after the administration of melatonin. ${ }^{80}$ It was found that people in most cases, onset of labor occurs late at night or in the early morning hours when melatonin secretion is increased. ${ }^{81-86}$ cervical ripening and disclosure of uterine throat occurs with greater frequency between 24.00 and 05.00 o'clock in the morning. ${ }^{87,88}$

Study of the role of melatonin in the labor and delivery mechanisms has shown that it increases the oxytocin-induced contraction of the myometrium with the participation of protein kinase $\mathrm{C}$ and protein
- connexin 43, acting through the MT2 receptors, which means it carries unidirectional oxytocin effects. ${ }^{89}$ In addition, he sensitizing cells to oxytocin of the myometrium. Its paracrine effect facilitates simultaneous reduction of smooth muscle cells. ${ }^{90}$ It is found that in utero melatonin receptor expression as high as oxytocin and therefore nocturnal melatonin levels rise significantly contributes to development of optimum labor and childbirth. ${ }^{54,66,67}$ It is shown that in bright lighting at night time peak melatonin secretion is suppressed, and this hinders the development of regular uterine contractions. ${ }^{67}$ The authors stress that in connection with the use of artificial light at night, especially in hospitals, there is a tendency to reduce the frequency of births in the night, and the development of the weakness of labor. ${ }^{54}$ Since melatonin enhances synergistically with oxytocin uterine contractions is proposed to use at the weakness of labor and labor induction with oxytocin and promote the synthesis of melatonin by changing generic lighting unit. ${ }^{91,92}$ Furthermore, installed anxiolytic and analgesic effects of melatonin and implementation mechanisms through receptors GHB and MT1, MT2, $\mu$ - opioid receptors and recovering $\beta$-endorphin, ${ }^{93-95}$ with the anxiolytic effect is much greater than that after administration of the preparations bezdiazepinovogo series. ${ }^{94,95,96}$ It is therefore proposed to use melatonin for sedation ${ }^{97}$ and painful contractions of myometrium. ${ }^{93,98}$ Melatonin for pain has been successfully used in neonatal intensive care children ${ }^{98}$ and its use in anesthetic practice can significantly reduce the dosage necessary for anesthetic preparations and provide an anxiolytic and anti-inflammatory effects in the postoperative period. ${ }^{48,74,94,95,99-102}$ Discussing the possible uses of melatonin in obstetrics authors emphasize the absence of adverse effects on the condition of the mother and child. ${ }^{71,91,103}$ In contrast, use of melatonin at complication of pregnancy gestosis contributes to significant improvement in the prevention of fetal life and delay its prenatal development. ${ }^{104}$ At the same time, it stresses the importance of an individual approach not only to the appointment of melatonin, but also drugs that suppress its secretion or seizing receptors. ${ }^{51,91}$ Thus, it is shown that agonist seduksen benzodiazepine receptors having GABA-ergic mechanisms as the other GABA-positive substances are physiological antagonists of norepinephrine, serotonin, melatonin, oxytocin and prostaglandin F $2 \alpha$ by the action on the uterus. ${ }^{75,105-108}$

Thus, increased in the last decade, the interest of researchers to study the physiological role of melatonin in the reproductive function has given sufficient evidence not only his chronotropic activity, but also a number of other pharmacologically valuable properties that determine the optimal course of pregnancy and childbirth, making a promising development of new approaches to its use in obstetrics. At the same time, existing data indicate the need for special attention to keeping in obstetric hospitals light conditions needed for the endogenous production of melatonin, as well as restrictions on the use of its suppressive drugs.

\section{Acknowledgements}

None.

\section{Conflict of interest}

Authors declare that there is no conflict of interest.

\section{References}

1. Bellipanni G, Bianchi P, Pierpaoli W, et al. Effects of melatonin in perimenopausal women and menopausal women: a randomized and placebo controlled study. Exp Gerontol. 2001;36(2):297-310. 
2. Forsling ML. Diurnal rhythms in neurohypophysial function. Exp Physiol. 2000;85:179-186.

3. Roenneberg T, Aschoff J. Annual rhythm of human reproduction. J Biol Rhythms. 1990;5(30):195-216.

4. Rohr UD, Herold J. Melatonibn deficiencies in women. Maturitas. 2002;41(Suppl 1):85-104.

5. Tsang AH, Barclay JL, Oster H. Interactions between endocrine and circadian systems. J Mol Endocrinol. 2014;52(1):1-16.

6. Boden MJ, Varcoe TJ, Kennaway DJ. Circadian regulation of reproduction: From gamete to offspring. Prog Biophys Mol Biol. 2013:113(3):387-397.

7. Hardeland R, Madrid JA, Tan DX, et al. Melatonin, the circadian multioscillator system and health: the need for detailed analyses of peripheral melatonin signaling. J Pineal Res. 2012;52(2):139-166.

8. Macchi MM, Bruce JN. Human pineal physiology and functional significance of melatonin. Front Neuroendocrinol. 2004;25(3-4):177195.

9. Schlabritz Loutsevitch N, Hellner N, Middendorf R, et al. The human myometrium as a target for melatonin. J Clin Endocrinol Metab. 2003;88(2):908-913.

10. Tamura H, Takasaki A, Taketani $\mathrm{T}$, et al. Melatonin as a free radical scavenger in the ovarian follicle. Endocr J. 2013;60(1):1-13.

11. Lerner AB, Case JD, Takahashi Y, et al. Isolation of melatonin, the pineal gland factor that lightens melanocytes. J Am Chem Soc. 1958; 80: 2587.

12. Rapoport, SI, Golichenkova VA Red. Melatonin: theory and practice. MID: Medpraktika; 2009.

13. Helimski AM. Epiphysis. Medicine. 1969.

14. Takahashi JS. Circadian rhythms. ICER is nicer at night (sir!). Curr Biol. 1994;4(2):165-168.

15. Anisimov VN. Melatonin a role in the body, clinical use. SPB System. 2007.

16. Maitra S, Baidya DK, Khanna P. Melatonin in perioperative medicine: Current perspective. Saudi J Anaesth. 2013;7(3):315-321.

17. Klein DC, Moore RY. Pineal N-acetyltransferase and hdroxyindoleO-methyltransferase: control by the retinohypothalamic tract and the suprachiasmatic nucleus. Brain Res. 1979;174(2):245-262.

18. Reiter RJ, Richardson BA, Matthews SA, et al. Rhythms of immunoreactive melatonin in the retina and Harderian glands of rats: persistence after pinealectomy. Life Sci. 1983;32(1):1229-1236.

19. Kvetnoy IM, Reichlin NT, Yuzhakov VV, et al. Ekstrapinealny melatonin: the place and role in the neuroendocrine regulation of homeostasis. Bull Exper Biol. 1999;127(4):364-370.

20. Abe M, Itoh MT, Miyata M, et al. Circadian rhythm of serotonin N-acetyltransferace activity in rat lens. Exp Eye Res. 2000;70(6):805808.

21. Kvetnoy IM. Extrapineal melatonin: location and role within diffuse neuroendocrine system. Histochem J. 1999;31(1):1-12.

22. Kvetnoy I, Sandvik AK, Waldum HL. The diffuse neuroendocrine system and extrapineal melatonin. J Mol Endocrinol. 1997;18(1):1-3.

23. Leunay JM, Lemaitre BJ, Husson HP, et al. Melatonin synthesis by rabbit platelets. Life Sci.1982;31(14):1487-1494.

24. Tan DX, Manchester LC, Liu X, et al. Mitochondria and chloroplasts as the original sites of melatonin synthesis: a hypothesis related to melatonin's primary function and evolution in eukaryotes. J Pineal Res. 2013;54(2):127-138.
25. Venegas C, Garcia JA, Escames G, et al. Extrapineal melatonin analysis of its subcellular distribution and daily fluctuations. J Pineal Res. 2012;52(2):217-227.

26. Reiter RJ, Tan DX, Korkmaz A, et al. Melatonin and stable circadian rhythms optimize maternal, placental and fetal physiology. Hum Reprod Update. 2014;20(2):293-307.

27. Cardinali DP, Lynch HJ, Wurtman RJ. Binding of melatonin to human and rat plasma proteins. Endocrinology. 1972;91(5):1213-1218.

28. Mallo C, Zaidan R, Galy G, et al. Pharmacokinetics of melatonin in man after intravenous infusion and bolus injection. Eur J Clin Pharmacol. 1990;38(3):297-301

29. Dubocovich ML. Melatonin receptors: role on sleep and circadian rhythm regulation. Sleep Med. 2007;8(Suppl 3):34-42.

30. Reppert SM, Godson C, Mahle CD, et al. Molecular characterization of a second melatonin receptor expressed in human retina and brain: the Mel1b melatonin receptor. Proc Natl Acad Sci USA. 1995;92(19):87348738 .

31. AlGhoulWM, Herman MD, Dubocovich ML. Melatonin receptor subtype expression in human cerebellum. Neuroreport. 1998;9(18):4063-4068.

32. Raikhlin NT, Kvetnoy IM. Melatonin and enterochromaffine cells. Acta Histochem. 1976;55(1):19-24.

33. Reppert SM, Weaver SA, Rivkees SA, et al. Putative melatonin receptors in a human biological clock. Science. 1988;242(4875):78-81.

34. Sanchez Barcelo EN, Hellner N, Middendorf R, et al. The human myometrium as a target for melatonin. J Clin Endocrinol Metab. 2003;88(2):908-913.

35. Vacas MI, Del Zar MM, Martinuzzo M, et al. Binding sites for [3H] melatonin in human platelets. J Pineal Res. 1992;13(2):60-65.

36. Yie SM, Niles LP, Youglai EV. Melatonin receptors on human granulose cell membranes. J Clin Endocrinol Metab. 1995;80(5):1747-1749.

37. Bedrosian TA, Herring KL, Walton GC, et al. Evidence for feedback control of pineal melatonin secretion. Neurosci Lett. 2013;542(10):123125 .

38. Reppert SM, Weaver DR, Ebisawa T, et al. Cloning of a melatonin-related receptor from human pituitary. FEBS Lett.1996;386(2-3):219-224.

39. Benitez King G. Calmodulin mediates melatonin cytoskeletal effects. Experientia. 1993;49(8):635-641.

40. Fjaerli O, Lund T, Osterud B. The effect of melatonin on cellular activation processes in human blood. J Pineal Res. 1999;26(1):50-55.

41. Bojanowska, Forsling ML. The effect of melatonin on vasopressin secretion in vivo:. Interactions with acetylcholine and prostaglandins. Brain Res Bul. 1997;42(6):457-461.

42. Forsling ML, Stoughton R, Zhou Y, et al. The role of the pineal in the control of patterns of neurohypophysial hormone secretion. J Pineal Res. 1993;14(1):45-51.

43. Reiter RJ. Evidence for refractoriness of the pituitary-gonadal axis to the pineal gland in golden hamsters and its possible implications in annual reproductive rhythms. Anat Rec. 1972;173(3):365-371.

44. Shi L, Li N, Bo L, et al. Melatonin and hypothalamic-pituitary- gonadal axis. Curr Med Chem. 2013;20(15):2017-2031.

45. Slominski RM, Reiter RJ, Schlabritz Loutsevitch N, et al. Melatonin membrane receptors in peripheral tissues: distribution and functions. Mol Cell Endocrinol. 2012;351(2):152-166.

46. El Raey M, Geshi M, Somfai T, et al. Evidence of melatonin synthesis in the cumulus oocyte complexes and its role in enhancing oocyte maturation in vitro in cattle. Mol Reprod Dev. 2011;78(4):250-262. 
47. Maganhin CC, Fuchs LF, Simoes RS, et al. Effects of melatonin on ovarian follicles. Eur J Obstet Gynecol Reprod Biol. 2013;166(2):178184.

48. Maitra SK, Chattoraj A, Mukherjee S, et al. Melatonin: a poten candidate in the regulation of fish oocyte growth and maturation. Gen Comp Endocrinol. 2013;181:215-222.

49. Tamura H, Nakamura Y, Terron MP, et al. Melatonin and pregnancy in the human. Reprod Toxicol. 2008;25(3):291-303.

50. Galano A, Tan DX, Reiter RJ. On the free radical scavenging activities of melatonin's metabolites, AFMK and AMK. J Pineal Res. 2013;54(3):245-257.

51. Korkmaz A, Reiter RJ, Topal T, et al. Melatonin, an established antioxidant worthy of use in clinical trials. Mol Med. 2009;15(1-2):4350 .

52. Lanoix D, Lacasse AA, Reiter RJ, et al. Melatonin: the watchdog of villous trophoblast homeostasis against hypoxia / reoxygenation-induced oxidative stressand apoptosis. Mol Cell Endocrinol. 2013;38(1-2):3545 .

53. Milczarek R, Hallmann A, Sokolowska E, et al. Melatonin enhances antioxidant action of alpha-tocopherol and ascorbate against NADPH and iron-dependent lipid peroxidation in human placental mitochondria. J Pineal Res. 2010;49(2):149-155.

54. Reiter RJ, Rosales Corral SA, Manchester LC, et al. Peripheral Reproductive Organ Helth and Melatonin: Ready for Prime Time. Int $J$ Mol Sci. 2013;14(4):7231-7272.

55. Rodriguez C, Mayo JC, Sainz RM, et al. Regulation antioxidant enzymes: a significant role for melatonin. J Pineal Res. 2004;36(1):1-9.

56. Carrillo Vico A, Guerrero JM, Lardone PJ, et al. A review of the multiple actions of melatonin on the immune system. Endocrine. 2005;27(2):189200

57. Mauriz JL, Collado PS, Veneroso C, et al. A review of the molecular aspects of melatonin's anti-inflammatory actions: resent insights and new perspectives. J Pineal Res. 2013;54(1):1-14.

58. Urata $\mathrm{Y}$, Honma $\mathrm{S}$, Goto $\mathrm{S}$, et al. Melatonin induces gammaglutamylcysteine synthetase mediated by activator protein-I in Human vascular endothelial cells. Free Radic Bio Med. 1999;27(7-8):838-847.

59. Aylamazyan EK, Polyakov VO, Kvetnoy IM. Functional morphology of human placenta in normal and pathological conditions. SPB Publishing HL. 2012

60. Fingers MA, Kvetnoy IM. Neyroimmunoendokrinologii Guide. 2nd ed. JSC Publishing house Medicine. 2008.

61. Tan DX, Manchester LC, Terron MP, et al. One molecule, many derivates: a never - ending interactionj melatonin with reactive oxygen and nitrogen species? J Pineal Res. 2007;42(1):28-42.

62. Iwasaki, Nakazawa K, Sakai J, et al. Melatonin as a local regulator of human placental function. J Pineal Res. 2005;39(3):261-265.

63. Lanoix D, Berhdadi H, Lafond J, et al. Human placental trophoblasts synthesize melatonin and express its receptors. $J$ Pineal Res. 2008;45(1):50-60.

64. Kaneko Y, Hayaski T, Yu S, et al. Human amniotic epithelial cells express melatonin receptor NT1, but not melatonin receptor MT2: A new perspective on neuroprotection. J Pineal Res. 2011;50(3):272-280.

65. Mitchell MD, Sayers L, Keirse MJ, et al. Melatonin in amniotic fluid during human parturition. Br J Obstet Gynecol. 1978;85(9):684-686.

66. Kivela A. Serum melatonin during human pregnancy. Acta Endocrinol (Copengagen). 1991;124(3):233-237.
67. Nakamura Y, Tamura H, Kashida S, et al. Changes of serum melatonin level and its relationship to feto-placental unit during pregnancy. $J$ Pineal Res. 2001;30(1):29-31.

68. Lew GM. Morphological and biochemical shanges in the pineal gland in pregnancy. Life Sci.1987;41(24):2589-2596.

69. Lanoix D, Lacasse AA, Reiter RJ, et al. Melatonin: the smart killer: the human trophoblast as a model. Mol Cell Endocrinol. 2012;48(1):1-11.

70. Evsyukova II, Kovalchuk OV Kovalevskaya, Maslyanyuk NA, et al. Features of cyclic organization of sleep and melatonin production in healthy full-term newborns with intrauterine growth retardation. Fiziol. person. 2013;39(6):63-71

71. Chen YC, Sheen JM, Tiao MM, et al. Role of Melatonin in Fetal Programming in Compromised Pregnancies. Int $\mathrm{J} \mathrm{Mol} \mathrm{Sci}$. 2013;14:5380-5401.

72. Arthur P, Taggart MJ, Mitchell BF. Oxytocin and parturition: a role for increased myometrial calcium and calcium sensitization? Front Biosci. 2007;12(1):619-633.

73. Blanks AM, Shmygol A, Thornton S. Regulation of oxytocin receptor signaling. Semin Reprod Ned. 2007;25(1):52-59.

74. Taggart MJ, Arthur P, Zielnik B, et al. Molecular pathways regulating contractility in rat uterus through late gestation and parturition. $\mathrm{Am} \mathrm{J}$ Obstet Gynecol. 2012;207(1):15-24.

75. Abramchenko VV. Oxytocin and the female reproductive system. Akus Gynecol (Mosk). 1993;2:5-8

76. Kalinichenko LS, SS Pertsov, Koplik EV. Effect of melatonin on blood serum cytokine profile in rats with different parameters behavior during acute emotional stress. Bull Exper biol honey. 2013;156(11):569-573.

77. Bakker JJ, De Vos R, Pel M, et al. Start of induction of labour with oxytocin in the morning or in the evening. A randomised controlled trial. BJOG. 2009;116(4):562-568.

78. Roizen J, Luedke CE, Herzog ED, et al. Oxytocin in the Circadian Timing of Birth. PloS ONE. 2007;2(9):e922.

79. Olcese J. Circadian aspects of mammalian parturition: a review. Mol Cell Endocrinol. 2012;349(1):62-67.

80. Takayama H, Nakamura Y, Tamura H, et al. Pineal gland (melatonin) affects the parturition time, but not luteal function and fetal growth in pregnant rats. Endocr J. 2003;50(1):37-43.

81. Cagnacci A, Soldani R, Melis GB, et al. Diurnal rhythms of labor and delivery in women: modulation by parity and reasons. Am J Obst Gynecol. 1998;178(1):140-145.

82. Glattre E, Bjerkedal T. The 24-hour rhythmicity of birth. A populational study. Acta Obstet Gynecol Scand. 1983;62(1):31-36.

83. Iams JD, Newman RB, Thom EA, et al. Frequency of uterine contractions and the risk of spontaneous preterm delivery. $N$ Eng $J$ Med. 2002;346(4):250-255.

84. Lindow SW, Jha RR, Thompson JW. 24-hour rhythm to the onset of preterm labor. Br J Obstet Gynecol. 2000;107(9):1145-1148.

85. Olcese J, Lozier S, Paradise C. Melatonin and the circadian timing of human parturition. Reprod Sci. 2013;20(2):168-174.

86. Vatish TJ, Steer PJ, Blanks AM, et al. Diurnal variation is lost in Preterm deliveres before 28 weeks of gestation. BJOG. 2010;107:1145-1148.

87. Kaiser IH, Halberg F. Circadian periodic aspects of birth. Ann NY Acad Sci. 1962;98:1056-1068.

88. King PD. Increased frequency of birth in the morning hours. Science. 1956;123(3205):985-986. 
89. Sharkey JT, Puttaramu R, Word RA, et al. Melatonin Synergizes with Oxytocin to Enhance Contractility of Human Myometrial Smooth Muscle Cells. J Clin Endocrinol Metab. 2009;94(2):421-427.

90. Sharkey JT, Cable C, Olcese J. Melatonin Sensitizes Human Myometria Cells to Oxytocin in a Protein Kinase Ca / Extracellular-Signal Regulated Kinase-Dependent Manner. J Clin Endocrinol Metab. 2010;95(6):29022908 .

91. Reiter RJ. Melatonin: Clinical relevance. Best Pract Res Clin Endocrinol Metab. 2003;17(2):273-285.

92. Srinivasan V, Lauterbach EC, Ho KY, et al. Melatonin in antinociception: its therapeutic applications. Curr Neuropharmacol. 2012;10(2):167-178.

93. Esposito F, Paterniti I, Mazzon E, et al. Melatonin reduces hyperalgesia with inflammation. J Pineal Res. 2010;49(4):321-331.

94. Shavali S, Ho B, Govitrapong P, et al. Melatonin exerts its analgesic actions not by binding to opioid receptor subtopes but by increasing the release of beta-endorphin an endogenous opioid. Brain Res Bul. 2005;64(6):471-479.

95. Wilhelmsen M, Amirian I, Reiter RJ, et al. Analgetic effects of melatonin a review of current evidence from experimental and clinical studies. $J$ Pineal Res. 2011;51(3):270-277.

96. Arushanyan EB, EB Beyer, AS Bulgakov. Comparative evaluation antistress activity epiphyseal hormone melatonin and diazepam. Exper wedge Farmacol. 2007;70(6):9-12.

97. Lago P. Premedication for non-emergency intubation in the neonate Minerva Pediatr. 2010;62(3 Suppl 1):61-63.

98. Gitto E, Aversa S, Salpietro CD, et al. Pain in neonatal intensive care: role of melatonin as an analgesic antioxidant. J Pineal Res. 2012;52(3):291295.

99. Caumo W, Levandovski R, Hidalgo MP. Preoperatve anxiolytic effect of melatonin and clonidine on postoperative pain and morphine consumption in patients undergoing abdominal hysterectomy: a doubleblind, randomized, placebo-controller study. J Pain. 2009;10(1):100 108
100. Ismail SA, Mowafi HA. Melatonin provides anxiolysis, enhances analgesia, decreases intraocular pressure, and promotes better operating conditions during cataract surgery under topical anesthesia. Anesth Analg. 2009;108(4):1146-1151.

101. Mowafi HA, Ismail SA. Melatonin improves tourniquet tolerance and enhances postoperative analgesia in patients receiving intravenous regional anesthesia. Anesth. Analg. 2008;107(4):1422-1426.

102. Naquib M, Samarkandi A, Moniem MA, et al. Effects of melatonin premedication on propofol and thiopental induction dose- response curves: A prospective, randomized, double blind study. Anesth Analg. 2006;103(6):1448-1452.

103. Ogasawara T, Adachi N, Nishijima M. Melatonin levels in maternal plasma before and during delivery, and in fetal and neonatal plasma. Nihon Sanka Fujinka Gakkai Zasshi. 1991;43(3):335-341.

104. Bubenik GA, Blask DE, Brown GM, et al. Prospects on the clinical utilization of melatonin. Biol Signals Recept. 1998;7(4):195-219.

105. Gersamia TV, Kudrin AN, Corrosion GS. Effect of fentanyl and droperidol seduksena reactivity of the uterus of rats and prostaglandin F2ó. Problems Ochres Mater childhood. 1978;9:82.

106. Kudrin AN, Corrosion GS, Chernuha EA, et al. The action of prostaglandin F2ó, oxytocin, vetrazina on isolated human myometrium and the impact on their incentive effects of droperidol, diazepam, fentanyl. Akusha Gynecological. 1979;1:10-13.

107. Sizov PI. Effect of GABA - positive substances uterostimuliruyuschie effects of excitatory neurotransmitters, prostaglandin F2 $\alpha$ and oxytocin. Bull Exper Biol Honey. 1992;113(4):387-389.

108. Landesman R, Wilson KH. Relaxant effect of diazepam on uterine muscle. Obstet.Gynecol. 1965;26(4):552-556. 